\title{
What are the Key Factors Influencing the Formation Offarmers' Cooperatives? Empirical Analysis from 307 Villages in 25 Provinces of China
}

\author{
Wen, Hua \\ Central University of Finance and Economics \\ School of economics, Beijing 102200
}

\begin{abstract}
In China's agricultural history, small farmers have been the main agricultural business entities for thousands of years. Although China's agricultural business model was replaced by the collective business model during the planned economy period, the traditional farming techniques and methods have not been changed fundamentally. This is why China's agriculture has been stagnated for a long time. In order to break through the plight of "small farmers", since the late 1990s, the Chinese government has begun to cultivate new types of agricultural business entities. Among them, the farmercooperatives have received the widest attention. However, in practice, the formation of Chinese farmer cooperatives has encountered problems of low enthusiasm for farmers' participation and "false participation". In this regard, this paper analyzes the key influencing factors for the formation of farmer cooperatives from the perspective of farmers, and uses the data of 307 villages in 25 provinces of the CLDS (Chinese Labor force Dynamic Survey) to quantitatively analyze the impact of the nature of planted product and trust on the formation of cooperatives. The conclusions of this paper are as follows: (1) If the main planted crop is normal grain, the formation of cooperatives is affected by the scale of cultivated land; (2) If the main planted crop is commercial crops, the formation of cooperatives is affected by product characteristics;(3) Driven by interests, trust has a positive effect on the formation of cooperatives Therefore, this article proposes that to promote the development of famer cooperatives, full consideration should be given to the nature of the farmer's business products, and the implementation of agricultural organizational management countermeasures in light of local social trust.
\end{abstract}

Keywords: nature of planted product, trust,transaction cost reduction,cooperative formation

\section{Introduction and existing studies}

At the end of the 19th century, farmer cooperatives began to appear in the Europe, American continents and some Asian countries, and made great contributions to their agricultural development. Since the late 1990s, the Chinese government has begun to cultivate new types of agricultural business entities and vigorously supported the development of farmers' cooperatives (Huang,2000). According to official statistics, as of the end of 2018, SAIC (State Administration for Industry and Commerce) registered farmers' professional cooperatives had reached 1.754 million; members of the cooperative were 125.69 million. However, in practice, the formation of Chinese farmer cooperatives has encountered problems of low enthusiasm for farmers' participation and "false participation". For example, Sun and $\mathrm{Xu}$ (2012)conducted a field survey of 243 members of 30 farmer professional cooperatives in Jiangsu province and found that farmers who have joined the cooperative the willingness to further participate in cooperation is very weak. Luo et al(2017)pointed out that using official published data to estimate the participation rate of farmers 'cooperatives may greatly overestimate the "real" participation, because in reality, most farmers' participation may be " false participation ". Therefore, depth exploration of the internal mechanism behind the needs of farmers' organizations and analysis of the key influencing factors for the formation of farmers' cooperation have a higher guiding significance for further development of farmers' cooperatives.

At present, the relevant literature on the formation of farmers' cooperatives emphasizes more on institution, policies, human capital and governance structure, while neglecting the impact of the nature of farmers' business products (Guo and Jiang,2004;Huang et al.,2010; Huang and Gao,2012).However, the farmers' cooperatives that have been formed in China are mainly concentrated in the traditional grain planted areas and the eastern coastal areas where the product structure has shifted to commodity crop production (see Figure 1). According to the statistics of the Annual Report of China's Rural Economic Management, for the main grain producing areas, the number of farmers whose cultivated land area is more than $30 \mathrm{mu}$ is more, and the number of cooperatives is also higher (see Figure 2). As for the main production areas of economiccrops, the greater changes in the planting ratio of high commercialized crops, the higher number of cooperatives established (see Figure 3). Therefore, an intuitive conjecture is that the demand of farmers' organizations is related to the nature of their planted products. 
However, the research on the nature of planted products and the formation of cooperatives is limited. Therefore, this paper trying to give an answer to "What is the mechanism of the effect of the nature ofplanted products on the demand of farmers' cooperatives?".

In addition to the nature of planted products, another factor affecting the demand of farmers' organizations is trust. However, scholars pay more attention to the internal trust of cooperatives (Guo at el.,2008), and few consensus has been reached on the relationship between trust and cooperative formation. For example, Zhao and $\mathrm{Li}$ (2007) pointed out that China's social trust is a special relationship based on blood, geography and love, which makes it difficult for cooperatives to expand their member size and regional space. Xiong(2009) pointed out that the Chinese "human relationship society" is used to establishing the personal relationship in the socio-economic relationship, tends to gather the core rights in the hands of "related people", and prefers the family management mode. In response, Xu(2007)pointed out that Chinese farmers are not born with "good separation and poor integration". Zhao(2018) used the "interest-relationship-network" mechanism to question the negative relationship between trust and the formation of cooperative economy, saying that under the impact of interest, trust continues to spread through the relationship network and get rid of the "human situation dilemma". So, can the formation of Chinese farmers' cooperatives break through the "human predicament"? The answer is still unknown. Therefore, this paper continues to introduce trust and explore the relationship between trust and the formation of cooperatives under the impact of interests.

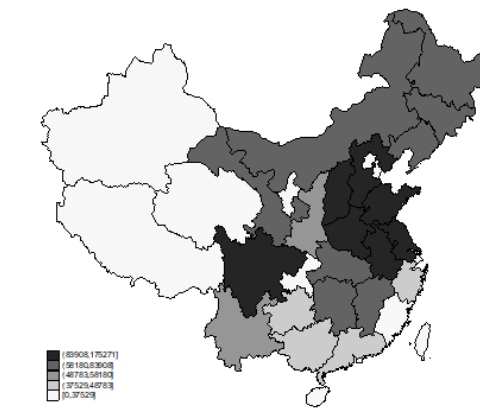

Figure 1: farmer cooperatives number in 2018

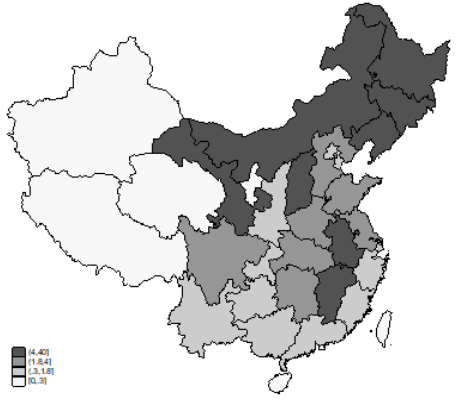

Figure 2: number of farmers whose cultivated land area is more than $30 \mathrm{mu}$

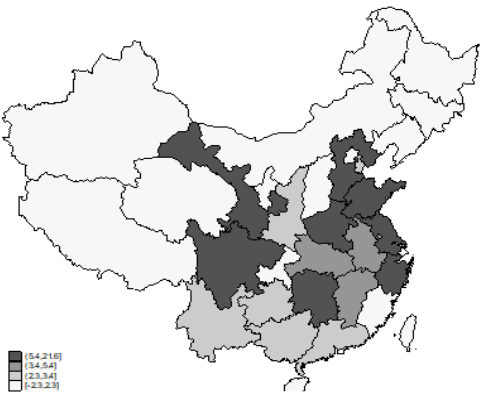

Figure 3: changes in the planting ratio of high commercialized crops

\section{Characteristics of agricultural management mode and research hypothesis}

According to the theory of transaction cost, as long as there is commodity economy, transaction cost must be accompanied (Coase ,1937,1960; Williamson,1979). In the industrial economy, enterprises have the function of reducing transaction cost. However, for China's agricultural economy, the organization of reducing transaction cost is in the absence. Since the promulgation of "the law of farmers' professional cooperatives" by the Chinese government in 2007, China's agricultural management mode has gradually changed, which is characterized by:

\section{Household management is declining, and multi-entity management is emerging}

The trend of farmland transfer can confirm the changes of the main entities of agricultural management in China. The proportion of household contracted cultivated land to total cultivated land management area decreased from $94.3 \%$ in 2010 to $86.3 \%$ in 2018 , with a total decrease of $8 \%$; while the proportion of transferred cultivated land to household contracted cultivated land increased from $14.7 \%$ in 2010 to $39.2 \%$, with a total increase of $24.5 \%$, indicating that the household contracted management is gradually declining. From the perspective of the flow direction of agricultural cultivated land, the area of cultivated land flowing to farmers has decreased year by year, with a decrease of $11.8 \%$ in 8 years, while the area of cultivated land flowing to farmers' professional cooperatives, enterprises and other main bodies has increased year by year, with a rise of $10.7 \%, 2.3 \%$ and $1.0 \%$ respectively in 8 years, of which the proportion of cultivated land flowing to farmers' professional cooperation has changed the most significantly 
Table1.Trend of farmland transfer

\begin{tabular}{|c|c|c|c|c|c|c|}
\hline & 2010 & 02015 & 2016 & 2017 & 2018 & $\begin{array}{l}2010- \\
2018\end{array}$ \\
\hline $\begin{array}{l}\text { Household contracted cultivated land / total } \\
\text { cultivated land }\end{array}$ & 0.943 & 0.923 & 0.903 & 0.909 & 0.863 & -0.080 \\
\hline Proportion of household contracted cultivated land & 0.147 & 0.333 & 0.351 & 0.370 & 0.392 & 0.245 \\
\hline Proportion of area transferred to farmers & 0.690 & 0.586 & 0.584 & 0.575 & 0.572 & -0.118 \\
\hline $\begin{array}{l}\text { Proportion of area transferred to professional } \\
\text { cooperatives }\end{array}$ & 0.118 & 0.218 & 0.2 & 0.227 & 0.225 & 0.107 \\
\hline Proportion of transferred to enterprise & 0.080 & 0.095 & 0.097 & 0.098 & 0.103 & 0.023 \\
\hline proportion of transferred to other main body & 0.091 & 0.101 & 0.104 & 0.100 & 0.100 & 0.010 \\
\hline
\end{tabular}

Data sources: Annual Report of China's Rural Economic Management

Grain crops cultivation are gathered, and economic crops cultivation are transferred to commercialized products

After the reform of opening-up, two significant changes have taken place in China's crops cultivation, first of all, the planting ratio of grain crops has become more and more concentrated. Although the total grain planting ratio in China has continued to decline, from $80.09 \%$ in 1980 to $70.94 \%$ in 2017, the grain planting ratio in major agricultural production areas has continued to rise, from $66.94 \%$ in 1980 to $75.21 \%$ in 2017. Secondly, the proportion of commercial crops is increasing. In 1980, China's commercial crop cultivation accounted for only $4.66 \%$ of the total cultivated land area of crops, but according to statistics in 2017, the value has risen to $20.43 \%$, indicating that China's economic crop planting structure has gradually shifted to highly commercialized crops to adapt to the development of market economy.

Table2.Trends in grain / economic crops cultivation

\begin{tabular}{|c|c|c|c|c|c|c|}
\hline \multirow{2}{*}{ Year } & \multirow{2}{*}{$\begin{array}{l}\text { Planting ratio } \\
\text { of total crops }\end{array}$} & \multirow{2}{*}{$\begin{array}{l}\text { Planting ratio } \\
\text { of grain crops }\end{array}$} & \multicolumn{3}{|c|}{$\begin{array}{l}\text { Planting ratio of general } \\
\text { economic crops }\end{array}$} & \multirow{2}{*}{$\begin{array}{l}\text { Planting ratio of } \\
\text {-high commercial } \\
\text { economic crops }\end{array}$} \\
\hline & & & oil & cotton & sugar & \\
\hline 1980 & 0.801 & 0.670 & 0.057 & 0.036 & 0.012 & 0.047 \\
\hline 1990 & 0.765 & 0.696 & 0.074 & 0.038 & 0.017 & 0.098 \\
\hline 2000 & 0.694 & 0.674 & 0.098 & 0.026 & 0.015 & 0.170 \\
\hline 2010 & 0.712 & 0.715 & 0.084 & 0.027 & 0.016 & 0.185 \\
\hline 2017 & 0.709 & 0.752 & 0.077 & 0.019 & 0.014 & 0.204 \\
\hline Annual average & 0.738 & 0.701 & 0.078 & 0.029 & 0.015 & 0.141 \\
\hline $\begin{array}{l}\text { Annual averag } \\
\text { change }\end{array}$ & -0.092 & 0.082 & 0.020 & 0.017 & 0.003 & 0.157 \\
\hline
\end{tabular}

Data source: China Rural Statistical Yearbook

China's agricultural management mode is changing simultaneously with its product production structure, so how does the nature of the planted product affect the farmers' organizational behavior?According to the theory of transaction cost, the nature of planted products is the main factor to determine transaction cost. The reason is that the nature of planted products determines the transaction cost through its own physical characteristics, the characteristics of market supply and demand elasticity and the characteristics of factor input.

Grain crops are physically durable and easy to store. They usually have one-time transactions with the market, with low transaction frequency. In market transactions, they have low demand elasticity. In order to support agriculture, the government usually provides protection prices and unified purchase services for grain crops, so that the transaction uncertainty can be alleviated. In factor inputs, they are characterized by intensive cultivated land, while cultivated landarea endogenous determines the input scale of factors. To sum up, for griain crops, the scale of cultivated land becomes the key factor to determine the transaction cost. Based on this, this paper proposes first hypothesis:

Hypothesis 1: If the main planted crop is normal grain, the formation of cooperatives is affected by the scale of cultivated land. 
Different from grain crops, commodity crops are physically easy to be consumed and hard to store. They usually have multiple transactions with the market, with high transaction frequency. In market transactions, they have high demand elasticity, which indicates that when prices fluctuate greatly, farmers are faced with risks such as "unable to sell" or "cheap to sell", so there is high transaction uncertainty.In factor input, the resource endowments exogenous determine the scale of production investment. To sum up, it is found that for commodity crops, the transaction frequency and uncertainty are the key factors that constitute the transaction cost. Because the product characteristics endogenously determine the transaction frequency and uncertainty, sofor commodity crops, the product characteristics are the key factors that determine the transaction cost. Based on this, this paper proposes second hypothesis:

\section{Hypothesis 2: If the main planted crop is commercial crops, the formation of cooperatives is affected by product characteristics.}

In the famer cooperatives economy, farmers face two costs: the transaction cost paid to reach an exchange with the market and the organizational cost paid to establishcooperatives. In this paper, the organization cost is divided into two parts: explicit cost and implicit cost. Explicit cost includes membership fee, operation fee and management fee (also known as "fixed cost"); while implicit cost refers to the risk cost of other members' opportunism faced by farmers' participation in cooperatives, which is the risk expectation of other members' behavior under incomplete information.Driven by the reduction of transaction cost, trustas social capital, can reduce the risk expectation of private opportunism and the cost of implicit organization. Based on this, this paper proposes a third hypothesis.

\section{Hypothesis 3: Driven by interests, trust has a positive effect on the formation of cooperatives.}

\section{Data and variables}

\section{Data sources}

The data of this paper comes from CLDS (China labor force dynamic survey data), which is obtained by the social science survey center of SUN YAT-SEN University every two years, covering 307 villages in 25 provinces of China, among which village and household samples are selected by random stratified sampling method, with high representativeness.

\section{Variable selection}

Construction of core dependent variables: in order to ensure the robustness of the results, and also to facilitate the comparison with the previous results, this paper takes the existence of cooperatives in the village and the coverage of cooperative farmers as the core variables of cooperative formation.

Construction of core independent variables: based on Deng (2011) research, this paper divides the village's management products into four categories: grain crops, general economic crops, commodity economic crops I and commodityeconomic crops II. Secondly, for grain crops, according to hypothesis 1, this paper takes the per capita cultivated land size as the transaction cost alternative variable, and in order to make a comparative analysis with other types of products, this paper calculates the cultivated land area of different crops according to the product categories. For commodity crops, according to hypothesis 2 , this paper takes the characteristics of planted products as the core variable of transaction costs, and divides them into two categories: high commodity crops and low commodity crops. Finally, according to hypothesis 3 , this paper takes the relationship between village farmer as the proxy variable of trust.

Selection of control variables: referring to the existing research, this paper selects 15 reference variables of economic conditions, natural conditions, external shocks and farmers' quality. appendix 1 shows the basic description of all variables in this article.

\section{Model design and empirical results}

Probit model and logit model are widely used in the case of dependent variable discrete. The main difference between probit model and logit model is that probit model can't give a statistical explanation for the parameter $\beta$ of maximum likelihood estimation (MLE). Therefore, this paper chooses logit model to estimate.

\section{According to hypothesis 1, this paper assumes that the probability function of managing grain crops on famer's organizational behavior is:}

$$
P(C O O P Y=1 \mid X)=F\left(\beta_{1} r, \beta_{2} f, \beta_{3} q, \beta_{I} X\right)(1)
$$

Among them, $q$ represents the scale of cultivated land, $X$ represents the control variable, $\beta_{1}$ represents the marginal effect brought by the scale of cultivated land, and $\beta_{I}$ represents the marginal effect brought by the control variable. We test the scale effect by model (1). The first column of Table 3 is the total scale effect test. 
The result shows that the landscale coefficient is 0.008 , which is significantly positive at the level of $5 \%$. That is to say, for every 8.25 hectares $(1000 \mathrm{mu} / 15=66 \mathrm{HA})$ increase in the per capita total agricultural land scale, the probability of cooperative formation increases by one point, which indicates that the agricultural land scale has a positive effect on cooperative formation. However, the scale effect of total farmland can't reflect the scale effect of different types of crops. Therefore, the scale effect of different types of crops is tested according to the product category in column 2-5. The second and third columns are the scale effect of grain crops and grain / general economic crops. The regression results show that the land scale coefficients are 0.033 and 0.031 , which are significantly positive at the level of $1 \%$ and $5 \%$, indicating that the probability of cooperative formation increases by 1 point for every 2.22 hectares $(100 \mathrm{mu} / 15=$ 6.67) of per capita cultivated land scale of grain crops and general economic crops compared with other types of crops. The fourth and fifth columns are the scale effect tests of commodity crops I and II. The regression results show that land scale is not significant at the $10 \%$ statistical level, indicating that compared with other types of crops, the scale of commodity crops has no significant impact on the formation probability of cooperatives. In general, the above empirical results support hypothesis 1 , which shows that for grain crops, the scale of cultivated land is a significant factor affecting the formation of cooperatives.

In addition, from the conclusion of control variables, the development of non-agricultural economy is more powerful for the formation of cooperatives. This paper holds that non-agricultural economy intensifies market competition, and then stimulates organizational behavior to cope with the "disadvantage" of competition. The number of migrant farmers has a positive impact on the formation of cooperativesbecause of the high "labor surplus" in China's agriculture. Financial subsidies and support have a positive effect on the formation of cooperatives. This paper holds that the external impact will effectively reduce the cost of cooperatives, and then affect the expected income of farmers' cooperatives, and encourage farmers to establish cooperatives. Terrain plays a positive role in the formation of cooperatives. This paper explains that in severe terrain areas, there is higher transaction costs need to pay. In order to reduce this cost, it is easy to trigger cooperative behavior. The quality of leaders plays a positive role in the formation of cooperatives. This paper explains that the quality of leaders can encourage farmers to form cooperatives by improving the awareness of cooperatives. 
Table 3. The scale effect of different categories products on the formation of cooperatives

\begin{tabular}{|c|c|c|c|c|c|}
\hline & $\begin{array}{l}\mathrm{M}(1) \\
\text { Full } \\
\text { sample }\end{array}$ & $\begin{array}{l}\mathrm{M}(2) \\
\text { Managing } \\
\text { grain } \\
\text { crops }\end{array}$ & $\begin{array}{l}\mathrm{M}(3) \\
\text { Managing } \\
\text { (grain/general } \\
\text { economic) } \\
\text { crops }\end{array}$ & $\begin{array}{l}\mathrm{M}(4) \\
\text { Managing } \\
\text { (commercial } \\
\text { economic) } \\
\text { crops I } \\
\end{array}$ & $\begin{array}{l}\mathrm{M}(5) \\
\text { Managing } \\
\text { (commercial } \\
\text { economic) } \\
\text { crops II } \\
\end{array}$ \\
\hline Land_Scale & $0.008^{* * *}$ & $0.033^{* * * *}$ & $0.031^{* * *}$ & 0.024 & 0.002 \\
\hline & (2.09) & (2.68) & $(2.56)$ & (1.49) & $(0.40)$ \\
\hline Gdp & $\begin{array}{l}-0.010 \\
(-1.11)\end{array}$ & $\begin{array}{l}-0.008 \\
(-0.97)\end{array}$ & $\begin{array}{l}-0.009 \\
(-1.21)\end{array}$ & $\begin{array}{l}-0.010 \\
(-1.09)\end{array}$ & $\begin{array}{l}-0.010 \\
(-1.13)\end{array}$ \\
\hline $\begin{array}{l}\text { N_Agr_Ind } \\
\text { us }\end{array}$ & $0.112^{* * *}$ & $0.120^{* * *}$ & $0.123^{* * *}$ & $0.110^{* * *}$ & $0.110^{* * *}$ \\
\hline & $(2.62)$ & (2.84) & $(2.91)$ & $(2.54)$ & $(2.53)$ \\
\hline Agr_Lab & $\begin{array}{l}0.039 \\
(1.58)\end{array}$ & $\begin{array}{l}0.038 \\
(1.60)\end{array}$ & $\begin{array}{l}0.036 \\
(1.49)\end{array}$ & $\begin{array}{l}0.035 \\
(1.48)\end{array}$ & $\begin{array}{l}0.037 \\
(1.52)\end{array}$ \\
\hline Ari_Out & $\begin{array}{l}0.144^{* * *} \\
(2.16)\end{array}$ & $\begin{array}{l}0.140^{* * *} \\
(2.12)\end{array}$ & $\begin{array}{l}0.131^{*} \\
(1.95)\end{array}$ & $\begin{array}{l}0.159^{* *} \\
(2.43)\end{array}$ & $\begin{array}{l}0.166^{* *} \\
(2.53)\end{array}$ \\
\hline Terrain & $\begin{array}{l}0.069^{*} \\
(1.79)\end{array}$ & $\begin{array}{l}0.069^{*} \\
(1.78)\end{array}$ & $\begin{array}{l}0.065^{*} \\
(1.68)\end{array}$ & $\begin{array}{l}0.070^{*} \\
(1.80)\end{array}$ & $\begin{array}{l}0.070^{*} \\
(1.80)\end{array}$ \\
\hline Disaster & $\begin{array}{l}-0.021 \\
(-0.51)\end{array}$ & $\begin{array}{l}-0.003 \\
(-0.07)\end{array}$ & $\begin{array}{l}0.001 \\
(0.03)\end{array}$ & $\begin{array}{l}-0.010 \\
(-0.23)\end{array}$ & $\begin{array}{l}-0.015 \\
(-0.36)\end{array}$ \\
\hline Distance & $\begin{array}{l}0.001 \\
(0.90)\end{array}$ & $\begin{array}{l}0.001 \\
(1.21)\end{array}$ & $\begin{array}{l}0.001 \\
(1.03)\end{array}$ & $\begin{array}{l}0.001 \\
(1.12)\end{array}$ & $\begin{array}{l}0.001 \\
(1.21)\end{array}$ \\
\hline Fis_Sub & $\begin{array}{l}0.008^{*} \\
(1.92)\end{array}$ & $\begin{array}{l}0.008^{*} \\
(1.87)\end{array}$ & $\begin{array}{l}0.008^{*} \\
(1.78)\end{array}$ & $\begin{array}{l}0.008^{* *} \\
(1.97)\end{array}$ & $\begin{array}{l}0.008^{* *} \\
(1.98)\end{array}$ \\
\hline Fin_Sup & $\begin{array}{l}0.075^{* *} \\
(2.01)\end{array}$ & $\begin{array}{l}0.069^{*} \\
(1.87)\end{array}$ & $\begin{array}{l}0.071^{*} \\
(1.92)\end{array}$ & $\begin{array}{l}0.074^{*} \\
(1.95)\end{array}$ & $\begin{array}{l}0.076^{* *} \\
(2.03)\end{array}$ \\
\hline Infor_1 & $\begin{array}{l}-0.013 \\
(-0.48)\end{array}$ & $\begin{array}{l}-0.018 \\
(-0.71)\end{array}$ & $\begin{array}{l}-0.019 \\
(-0.74)\end{array}$ & $\begin{array}{l}-0.018 \\
(-0.67)\end{array}$ & $\begin{array}{l}-0.016 \\
(-0.62)\end{array}$ \\
\hline Infor_2 & $\begin{array}{l}0.001 \\
(0.02)\end{array}$ & $\begin{array}{l}0.004 \\
(0.11)\end{array}$ & $\begin{array}{l}0.004 \\
(0.10)\end{array}$ & $\begin{array}{l}-0.003 \\
(-0.07)\end{array}$ & $\begin{array}{l}-0.001 \\
(-0.03)\end{array}$ \\
\hline Infrastr & $\begin{array}{l}0.075 \\
(1.14)\end{array}$ & $\begin{array}{l}0.082 \\
(1.29)\end{array}$ & $\begin{array}{l}0.083 \\
(1.29)\end{array}$ & $\begin{array}{l}0.073 \\
(1.11)\end{array}$ & $\begin{array}{l}0.068 \\
(1.03)\end{array}$ \\
\hline Lead_skill & $\begin{array}{l}0.083^{*} \\
(1.95)\end{array}$ & $\begin{array}{l}0.069^{*} \\
(1.65)\end{array}$ & $\begin{array}{l}0.074^{*} \\
(1.76)\end{array}$ & $\begin{array}{l}0.083^{*} \\
(1.96)\end{array}$ & $\begin{array}{l}0.079^{*} \\
(1.85)\end{array}$ \\
\hline Far_Cogni & $\begin{array}{l}0.002 \\
(0.25)\end{array}$ & $\begin{array}{l}0.005 \\
(0.65)\end{array}$ & $\begin{array}{l}0.003 \\
(0.40)\end{array}$ & $\begin{array}{l}0.006 \\
(0.76)\end{array}$ & $\begin{array}{l}0.008 \\
(0.94)\end{array}$ \\
\hline Far_Hetro & $\begin{array}{l}0.002 \\
(0.64)\end{array}$ & $\begin{array}{l}0.002 \\
(0.70)\end{array}$ & $\begin{array}{l}0.002 \\
(0.70)\end{array}$ & $\begin{array}{l}0.001 \\
(0.60)\end{array}$ & $\begin{array}{l}0.001 \\
(0.57)\end{array}$ \\
\hline$N$ & 635 & 635 & 635 & 635 & 635 \\
\hline LR & -359.78 & 359.78 & -363.10 & -364.29 & -362.21 \\
\hline chi2 & 36.368 & 44.067 & 44.581 & 33.434 & 31.950 \\
\hline predict & $72.14 \%$ & $71.65 \%$ & $72.13 \%$ & $72.44 \%$ & $72.60 \%$ \\
\hline
\end{tabular}

Note: in brackets are the robust standard errors adjusted by cluster at village level, *,**, ***respectively represent the significance levels of $10 \%, 5 \%$ and $1 \%$. In the last column, $\mathrm{LR}$ and $\mathrm{CH} 2$ are coefficient joint significant test statistics, and predict is the estimated probability and true probability accuracy of response model. The higher the value, the higher the response fitting.

According to hypothesis 2 , this paper assumes that the probability function of managing commercial crops on famer's organizational behavior is:

$$
P(C O O P Y=1 \mid X)=F\left(\beta_{1} r, \beta_{2} f, \beta_{3} q, \beta_{I} X\right)
$$

Among them, $\beta_{1}$ represents the marginal effect caused by trading uncertainty, $\beta_{2}$ represents the marginal effect brought by trading frequency, $\beta_{3}$ represents the marginal effect brought by factor input scale, and $\beta_{I}$ represents the marginal effect brought by control variables. For commodity crops, because of thetransaction uncertainty and frequency are the unobservable variable, this paper classifies the economic crops into high commercialized crops and low 84 
commercialized crops according to the differences of characteristics of products, so as to analyze the impact of product characteristics on the formation of cooperatives. Table 3 shows the estimation results of model (2), in which columns 1 and 2 report the influence of the characteristics of commodity crops I on the formation of cooperatives. The main difference between them is that column 1 is based on graincrops and column 2 is based on grain / general economic crops. The estimated results show that prod_com_1 coefficient is about 0.10 , which is significant at the level of $10 \%$ and $5 \%$, indicating that the cooperative formation probability of managing commodity crops is about $10 \%$ higher than that of managinggrain crops. Moreover, there is no difference in the estimation of the first two coefficients, indicating that the characteristics of general economic crops are similar to those of grain crops, which belong to low commercialized crops. Columns 3 and 4 report the influence of the characteristics of commodity crops II on the formation of its cooperative, and the conclusion is basically consistent with that of commodity crops I. In general, the above results support hypothesis 2. Compared with the low commercialized crops, the high commercialized crops are more motivated to produce cooperative behavior because of the greater trading uncertainty and trading frequency.

Table 4. The product characteristics effect on the formation of cooperatives

\begin{tabular}{|c|c|c|c|c|c|}
\hline & $\mathrm{M}(1)$ & $\mathrm{M}(2)$ & & $\mathrm{M}(3)$ & $\mathrm{M}(4)$ \\
\hline & \multicolumn{3}{|c|}{ commodity crops I. } & \multicolumn{2}{|c|}{ commodity crops II } \\
\hline Prod_Com_1 & $\begin{array}{l}0.096^{*} \\
(1.80)\end{array}$ & $\begin{array}{l}0.096^{* *} \\
(2.07)\end{array}$ & Prod_Com_2 & $\begin{array}{l}0.102^{* *} \\
(2.03)\end{array}$ & $\begin{array}{l}0.096^{* *} \\
(2.07)\end{array}$ \\
\hline Land_Scale & $\begin{array}{l}0.044^{* * * *} \\
(2.86)\end{array}$ & $\begin{array}{l}0.044^{* * * *} \\
(3.04)\end{array}$ & Land_Scale & $\begin{array}{l}0.043^{* * * *} \\
(3.00)\end{array}$ & $\begin{array}{l}0.042^{* * *} \\
(3.01)\end{array}$ \\
\hline Gdp & $\begin{array}{l}0.000 \\
(0.02)\end{array}$ & $\begin{array}{l}-0.003 \\
(-0.19)\end{array}$ & Gdp & $\begin{array}{l}-0.010 \\
(-1.14)\end{array}$ & $\begin{array}{l}-0.010 \\
(-1.20)\end{array}$ \\
\hline Agr_Indus & $\begin{array}{l}0.144^{* * * *} \\
(2.99)\end{array}$ & $\begin{array}{l}0.136^{* * * * *} \\
(3.05)\end{array}$ & Agr_Indus & $\begin{array}{l}0.129^{* * * *} \\
(2.89)\end{array}$ & $\begin{array}{l}0.121^{* * * *} \\
(2.87)\end{array}$ \\
\hline Agr_Lab & $\begin{array}{l}0.039 \\
(1.31)\end{array}$ & $\begin{array}{l}0.034 \\
(1.36)\end{array}$ & Agr_Lab & $\begin{array}{l}0.037 \\
(1.35)\end{array}$ & $\begin{array}{l}0.031 \\
(1.30)\end{array}$ \\
\hline Ari_Out & $\begin{array}{l}0.115 \\
(1.58)\end{array}$ & $\begin{array}{l}0.135^{*} \\
(1.92)\end{array}$ & Ari_Out & $\begin{array}{l}0.093 \\
(1.35)\end{array}$ & $\begin{array}{l}0.136^{* * *} \\
(2.03)\end{array}$ \\
\hline Terrain & $\begin{array}{l}0.076^{*} \\
(1.73)\end{array}$ & $\begin{array}{l}0.075^{*} \\
(1.84)\end{array}$ & Terrain & $\begin{array}{l}0.067^{*} \\
(1.65)\end{array}$ & $\begin{array}{l}0.070^{*} \\
(1.82)\end{array}$ \\
\hline Disaster & $\begin{array}{l}0.008 \\
(0.17)\end{array}$ & $\begin{array}{l}-0.000 \\
(-0.00)\end{array}$ & Disaster & $\begin{array}{l}0.008 \\
(0.19)\end{array}$ & $\begin{array}{l}0.003 \\
(0.07)\end{array}$ \\
\hline Distace & $\begin{array}{l}0.001 \\
(0.51)\end{array}$ & $\begin{array}{l}0.001 \\
(0.67)\end{array}$ & Distace & $\begin{array}{l}0.001 \\
(0.63)\end{array}$ & $\begin{array}{l}0.001 \\
(0.71)\end{array}$ \\
\hline Fis_Sub & $\begin{array}{l}0.013^{* *} \\
(2.04)\end{array}$ & $\begin{array}{l}0.010^{* *} \\
(2.02)\end{array}$ & Fis_Sub & $\begin{array}{l}0.010^{*} \\
(1.90)\end{array}$ & $\begin{array}{l}0.007^{*} \\
(1.73)\end{array}$ \\
\hline Fin_Sup & $\begin{array}{l}0.073 \\
(1.64)\end{array}$ & $\begin{array}{l}0.079^{* *} \\
(1.97)\end{array}$ & Fin_suo & $\begin{array}{l}0.061 \\
(1.48)\end{array}$ & $\begin{array}{l}0.075^{\text {** }} \\
(2.01)\end{array}$ \\
\hline Infor_1 & $\begin{array}{l}-0.005 \\
(-0.17)\end{array}$ & $\begin{array}{l}-0.014 \\
(-0.53)\end{array}$ & Infor_1 & $\begin{array}{l}-0.016 \\
(-0.59)\end{array}$ & $\begin{array}{l}-0.021 \\
(-0.82)\end{array}$ \\
\hline Infor_2 & $\begin{array}{l}0.027 \\
(0.60)\end{array}$ & $\begin{array}{l}0.025 \\
(0.59)\end{array}$ & Infor_2 & $\begin{array}{l}0.008 \\
(0.19)\end{array}$ & $\begin{array}{l}0.005 \\
(0.14)\end{array}$ \\
\hline Infrastr & $\begin{array}{l}0.028 \\
(0.38)\end{array}$ & $\begin{array}{l}0.061 \\
(0.88)\end{array}$ & Infrastr & $\begin{array}{l}0.070 \\
(1.01)\end{array}$ & $\begin{array}{l}0.084 \\
(1.31)\end{array}$ \\
\hline Lead_skill & $\begin{array}{l}0.089^{*} \\
(1.84)\end{array}$ & $\begin{array}{l}0.076^{*} \\
(1.72)\end{array}$ & Lead_skill & $\begin{array}{l}0.089^{* *} \\
(1.98)\end{array}$ & $\begin{array}{l}0.075^{*} \\
(1.81)\end{array}$ \\
\hline Far_Cogni & $\begin{array}{l}0.006 \\
(0.62)\end{array}$ & $\begin{array}{l}0.003 \\
(0.34)\end{array}$ & Far_Cogni & $\begin{array}{l}0.003 \\
(0.35)\end{array}$ & $\begin{array}{l}0.001 \\
(0.14)\end{array}$ \\
\hline Far_Hetro & $\begin{array}{l}-0.000 \\
(-0.01)\end{array}$ & $\begin{array}{l}0.001 \\
(0.38)\end{array}$ & Far_Hetro & $\begin{array}{l}0.000 \\
(0.16)\end{array}$ & $\begin{array}{l}0.001 \\
(0.57)\end{array}$ \\
\hline$N$ & 487 & 567 & $N$ & 555 & 635 \\
\hline LR & -276.23 & -318.49 & LR & -315.13 & -358.16 \\
\hline chi2 & 40.880 & 43.159 & chi2 & 43.555 & 44.772 \\
\hline predict & $71.87 \%$ & $71.96 \%$ & predict & $71.71 \%$ & $71.81 \%$ \\
\hline
\end{tabular}


Note: in brackets are the robust standard errors adjusted by cluster at village level, $*, * *, * * *$ respectively represent the significance levels of $10 \%, 5 \%$ and $1 \%$. In the last column, $\mathrm{LR}$ and $\mathrm{CH} 2$ are coefficient joint significant test statistics, and predict is the estimated probability and true probability accuracy of response model. The higher the value, the higher the response fitting.

According to hypothesis 3, the probability function of social trust influencing farmers' organizational behavior is as follows:

$$
P(C O O P Y=1 \mid X)=F\left(\beta_{1} r, \beta_{2} f, \beta_{3} q, \beta_{4} T, \beta_{I} X\right)(3)
$$

The coefficient $\beta_{4}$ represents the marginal effect of social trust. In order to more intuitively feel the positive effect of trust on the formation of cooperatives, this paper directly appends the virtual variables of trust to scale effect and commodity characteristics, forming scale * trust and prod $*$ trust items, so as to analyze the relationship between trust and cooperative formation. Table 4 shows the estimated results of model (3), among which the first five columns report the scale effect. From the regression results, compared with the individual scale effect, the coefficients in this model have increased. For this reason, this paper believes that the scale effect improves the probability of cooperative formation under the impact of trust, indicating that trust plays a positive role in the formation of cooperatives. Column 6-9 reports the product characteristic effect. The results show that compared with the individual product characteristic effect, the coefficients in this model have increased. For this reason, the product characteristic effect improves the probability of cooperation formation under the influence of trust, which shows that trust plays a positive role in cooperation formation. In general, the above empirical results support hypothesis 3, which shows that trust has a positive effect on the formation of cooperatives driven by the reduction of transaction cost of product characteristics effect and the scale effect. 
Table 5. The trust effect on the formation of cooperatives

\begin{tabular}{|c|c|c|c|c|c|c|c|c|c|}
\hline & $\mathrm{M}(1)$ & $\mathrm{M}(2)$ & $\mathrm{M}(3)$ & $\mathrm{M}(4)$ & $\mathrm{M}(5)$ & $\mathrm{M}(6)$ & $\mathrm{M}(7)$ & $\mathrm{M}(8)$ & $\mathrm{M}(9)$ \\
\hline \multirow{2}{*}{$\begin{array}{l}\text { Scale*Tru } \\
\text { st }\end{array}$} & 0.010 & $0.040^{*}$ & $0.034^{* * *}$ & $0.030^{*}$ & 0.005 & $0.049^{*}$ & $0.049^{*}$ & $0.043^{* * *}$ & $0.040^{*}$ \\
\hline & (2.68) & $(3.01)$ & $(2.73)$ & $(1.85)$ & $(1.27)$ & $(3.23)$ & $(3.26)$ & (3.24) & $(3.00)$ \\
\hline \multirow[t]{2}{*}{$\begin{array}{l}\text { Prod*Tru } \\
\text { st }\end{array}$} & & & & & & $0.127^{*}$ & $0.131^{*}$ & $0.130^{* *}$ & 0.104 \\
\hline & & & & & & $(2.77)$ & $(3.00)$ & (2.91) & (1.94) \\
\hline \multirow[t]{2}{*}{ Gdp } & -0.009 & -0.009 & -0.010 & -0.010 & -0.010 & -0.001 & -0.004 & -0.010 & -0.009 \\
\hline & $(-1.15)$ & $(-0.99)$ & $(-1.28)$ & $(-1.10)$ & $(-1.12)$ & $(-0.02)$ & $(-0.25)$ & $(-1.24)$ & $(-1.21)$ \\
\hline \multirow{2}{*}{$\begin{array}{l}\text { Agr_Indu } \\
\mathrm{s}\end{array}$} & $0.114^{* * *}$ & $0.119^{* * *}$ & $0.122^{* * *}$ & $0.110^{* * *}$ & $0.111^{*}$ & $0.147^{*}$ & $0.139^{*}$ & $0.131^{* * *}$ & $0.125^{*}$ \\
\hline & (2.68) & $(2.81)$ & $(2.86)$ & $(2.54)$ & $(2.56)$ & (3.09) & $(3.16)$ & $(2.95)$ & (2.99) \\
\hline \multirow{2}{*}{ Agr_Lab } & $0.040^{*}$ & $0.042^{*}$ & 0.039 & 0.036 & 0.037 & $0.052^{*}$ & $0.044^{*}$ & $0.047^{*}$ & 0.033 \\
\hline & (1.65) & $(1.76)$ & (1.63) & $(1.48)$ & $(1.53)$ & $(1.74)$ & $(1.74)$ & (1.74) & $(1.41)$ \\
\hline \multirow[t]{2}{*}{ Ari_Out } & $0.143^{\text {*** }}$ & $0.147^{* *}$ & $0.139^{* *}$ & $0.159^{* *}$ & $0.164^{*}$ & $0.129^{*}$ & $0.151^{*}$ & 0.105 & $0.141^{*}$ \\
\hline & (2.17) & $(2.25)$ & (2.10) & $(2.44)$ & $(2.50)$ & (1.77) & $(2.16)$ & $(1.55)$ & (2.08) \\
\hline \multirow[t]{2}{*}{ Terrain } & $0.075^{*}$ & $0.069^{*}$ & $0.065^{*}$ & $0.071^{*}$ & $0.072^{*}$ & $0.077^{*}$ & $0.076^{*}$ & $0.067^{*}$ & $0.067^{*}$ \\
\hline & (1.96) & (1.79) & $(1.70)$ & $(1.83)$ & $(1.85)$ & (1.76) & $(1.87)$ & (1.66) & (1.74) \\
\hline \multirow[t]{2}{*}{ Disaster } & -0.021 & -0.003 & -0.000 & -0.012 & -0.016 & 0.006 & -0.001 & 0.003 & 0.002 \\
\hline & $(-0.52)$ & $(-0.08)$ & $(-0.01)$ & $(-0.28)$ & $(-0.38)$ & $(0.12)$ & $(-0.03)$ & $(0.07)$ & $(0.06)$ \\
\hline \multirow[t]{2}{*}{ Distace } & 0.001 & 0.001 & 0.001 & 0.001 & 0.001 & 0.001 & 0.001 & 0.001 & 0.001 \\
\hline & $(0.99)_{*}$ & $(1.11)_{*}$ & $(1.01)_{*}$ & $(1.22)_{*}$ & $(1.19)_{*}$ & $(0.57)$ & $(0.72)$ & $(0.82)$ & $(0.90)$ \\
\hline \multirow[t]{2}{*}{ Fis_Sub } & $0.008^{*}$ & $0.008^{*}$ & $0.008^{*}$ & $0.008^{*}$ & $0.008^{*}$ & $0.012^{*}$ & $0.009^{*}$ & $0.010^{* *}$ & $0.007^{*}$ \\
\hline & $(1.95)$ & $(1.81)$ & $(1.80)$ & $(1.92)$ & $(1.97)$ & $(2.06)$ & $(2.00)$ & $(2.01)$ & $(1.72)$ \\
\hline \multirow[t]{2}{*}{ Fin_Sup } & $0.074^{* *}$ & $0.064^{*}$ & $0.067^{*}$ & $0.075^{* *}$ & $0.077^{*}$ & 0.067 & $0.076^{*}$ & 0.056 & $0.076^{*}$ \\
\hline & (1.98) & $(1.72)$ & (1.79) & $(2.02)$ & $(2.06)$ & $(1.52)$ & $(1.89)$ & $(1.36)$ & (2.04) \\
\hline \multirow[t]{2}{*}{ Infor_1 } & -0.013 & -0.020 & -0.020 & -0.019 & -0.016 & -0.009 & -0.017 & -0.018 & -0.020 \\
\hline & $(-0.48)$ & $(-0.79)$ & $(-0.77)$ & $(-0.73)$ & $(-0.60)$ & $(-0.30)$ & $(-0.63)$ & $(-0.65)$ & $(-0.80)$ \\
\hline \multirow[t]{2}{*}{ Infor_2 } & 0.003 & 0.007 & 0.008 & -0.003 & -0.001 & 0.033 & 0.029 & 0.014 & 0.005 \\
\hline & $(0.07)$ & $(0.20)$ & $(0.21)$ & $(-0.07)$ & $(-0.03)$ & $(0.73)$ & $(0.70)$ & $(0.35)$ & $(0.14)$ \\
\hline \multirow[t]{2}{*}{ Infrastr } & 0.074 & 0.082 & 0.077 & 0.074 & 0.069 & 0.029 & 0.059 & 0.062 & 0.083 \\
\hline & $(1.13)$ & $(1.27)$ & $(1.20)_{*}$ & $(1.13)$ & $(1.05)$ & $(0.39)$ & $(0.87)$ & $(0.92)$ & $(1.30)_{*}$ \\
\hline \multirow{2}{*}{$\begin{array}{l}\text { Lead_skil } \\
1\end{array}$} & $0.081^{*}$ & 0.066 & $0.071^{*}$ & $0.083^{*}$ & $0.079^{*}$ & $0.084^{*}$ & 0.071 & $0.085^{*}$ & $0.075^{*}$ \\
\hline & (1.92) & $(1.55)$ & (1.68) & (1.94) & (1.87) & (1.71) & (1.60) & (1.84) & $(1.80)$ \\
\hline \multirow{2}{*}{$\begin{array}{l}\text { Far_Cogn } \\
\mathrm{i}\end{array}$} & 0.004 & 0.009 & 0.007 & 0.006 & 0.007 & 0.012 & 0.009 & 0.010 & 0.002 \\
\hline & $(0.46)$ & (1.11) & $(0.90)$ & $(0.73)$ & $(0.82)$ & $(1.30)$ & $(0.97)$ & (1.07) & $(0.19)$ \\
\hline \multirow[t]{2}{*}{ Far_Hetro } & 0.001 & 0.001 & 0.001 & 0.001 & 0.001 & -0.000 & 0.001 & 0.000 & 0.001 \\
\hline & $(0.61)$ & $(0.62)$ & $(0.64)$ & $(0.62)$ & $(0.57)$ & $(-0.09)$ & $(0.29)$ & $(0.12)$ & $(0.58)$ \\
\hline$N$ & 635 & 635 & 635 & 635 & 635 & 487 & 567 & 555 & 635 \\
\hline \multirow[t]{2}{*}{ LR } & - & - & - & - & - & - & - & - & - \\
\hline & 359.14 & 359.49 & 362.71 & 363.87 & 360.82 & 273.50 & 315.93 & 312.83 & 357.83 \\
\hline chi2 & 40.444 & 46.763 & 44.982 & 34.466 & 32.927 & 46.083 & 48.218 & 47.078 & 46.340 \\
\hline \multirow{2}{*}{ predict } & 72.60 & 71.65 & 71.81 & 72.91 & 72.76 & 72.28 & 73.72 & 72.79 & 72.60 \\
\hline & $\%$ & $\%$ & $\%$ & $\%$ & $\%$ & $\%$ & $\%$ & $\%$ & $\%$ \\
\hline
\end{tabular}

Note: in brackets are the robust standard errors adjusted by cluster at village level, *,**,***respectively represent the significance levels of $10 \%, 5 \%$ and $1 \%$. In the last column, LR and $\mathrm{CH} 2$ are coefficient joint significant test statistics, and predict is the estimated probability and true probability accuracy of response model. The higher the value, the higher the response fitting. 


\section{Analysis on the Formation of Cooperatives based on the Coverage of Farmer}

Generally, the formation of cooperatives is measured by two indicators, one is whether farmers set up cooperatives, which is measured by "existence or not"; the other is the coverage degree of farmers of cooperatives, which is measured by the "coverage ratio of farmers" of existing cooperatives. Can the above conclusion still be true when the farmer coverage of cooperatives is used to refer to the formation of cooperatives? In order to reflect the information of farmers' coverage more comprehensively, this paper regards the farmers' coverage of each village as an independent event (0-100), and establishes a Negative Binomial Regression model andZero -inflated Negative Binomial Regression model for analysis.

Column 1-4 of table 5 ofestimate 1 reports the test results of hypothesis 1 usingNegative Binomial Regression analysis, including the influence of scale effect of grain crops, grain and general economic crops, commodity crops I and commodity crops II on the probability of cooperative formation.Among them, the first two columns of land scale coefficient are significantly positive at the level of $1 \%$, while the second two columns are not significant at the level of $10 \%$, indicating that for grain crops, the motivation of obtaining scale effect significantly increases the possibility of farmers participating in cooperative organizations. This conclusion further supports the rationality of hypothesis 1 . Column 1-4 of estimate 2 reports the impact of product characteristics on the formation probability of cooperatives. The conclusion shows that compared with low commercialized crops, farmers who managing high commercialized crops are more likely to participate in cooperative organizations. This conclusion further supports the rationality of hypothesis 2. Column 1-4 of estimate 3 reports the influence of scale effect and product characteristics effect on the possibility of farmers' participation in cooperative organizations under the influence of trust.

The results show that the coefficient is significantly positive at the level of $1 \%$ and $5 \%$, and compared with the individual scale effect and product characteristics effect, the coefficient is improved, indicating that scale effect and product characteristics effect may have a positive effect on farmers' participation in cooperative organizations under the impact of private trust orientation. This conclusion further supports the rationality of hypothesis 3. Column 5-8 of table 5 reports the estimated results using the Zero -inflated Negative Binomial Regression model, which are basically consistent with the Negative Binomial Regression results. Therefore, this paper holds that the original hypothesis is still true when farmers' coverage is used to refer to the formation of cooperatives.

Table 6 Analysis on the formation of cooperatives based on the coverage of farmer

\begin{tabular}{|c|c|c|c|c|c|c|c|c|}
\hline & $\mathrm{M}(1)$ & $\mathrm{M}(2)$ & $\mathrm{M}(3)$ & $\mathrm{M}(4)$ & $\mathrm{M}(5)$ & $\mathrm{M}(6)$ & $\mathrm{M}(7)$ & $\mathrm{M}(8)$ \\
\hline & \multicolumn{4}{|c|}{ NB regression model } & \multicolumn{4}{|c|}{ Z_NB regression model } \\
\hline \multicolumn{9}{|l|}{ Estimate 1} \\
\hline Land_Scale & $\begin{array}{l}2.041^{* * *} \\
(3.01)\end{array}$ & $\begin{array}{r}2.176^{* * * *} \\
(2.77)\end{array}$ & $\begin{array}{l}-0.105 \\
(-0.07)\end{array}$ & $\begin{array}{l}0.162 \\
(0.59)\end{array}$ & $\begin{array}{l}1.963^{* * *} \\
(2.79)\end{array}$ & $\begin{array}{l}1.702^{* * *} \\
(2.68)\end{array}$ & $\begin{array}{l}-0.142 \\
(-0.12)\end{array}$ & $\begin{array}{l}0.321 \\
(0.95)\end{array}$ \\
\hline Control var & Yes & Yes & Yes & Yes & Yes & Yes & Yes & Yes \\
\hline $\mathrm{N}$ & 635 & 635 & 635 & 635 & 635 & 635 & 635 & 635 \\
\hline \multicolumn{9}{|l|}{ Estimate 2} \\
\hline Prod_Com & $\begin{array}{l}9.621^{* * *} \\
(2.06)\end{array}$ & $\begin{array}{l}6.993^{* * *} \\
(2.04)\end{array}$ & $\begin{array}{l}12.651^{* * *} \\
(2.20)\end{array}$ & $\begin{array}{l}5.333^{*} \\
(1.66)\end{array}$ & $\begin{array}{l}8.243^{* *} \\
(2.12)\end{array}$ & $\begin{array}{l}5.065^{*} \\
(1.79)\end{array}$ & $\begin{array}{l}6.707^{* *} \\
(2.02)\end{array}$ & $\begin{array}{l}6.175^{* *} \\
(2.00)\end{array}$ \\
\hline Land_scale & $1.534^{*}$ & $1.303^{*}$ & $2.429^{*}$ & $1.687^{*}$ & $2.544^{* *}$ & $1.695^{* *}$ & $1.918^{* *}$ & $1.876^{* *}$ \\
\hline *Prod_Fc & $(1.86)$ & $(1.88)$ & $(1.88)$ & (1.89) & $(2.20)$ & $(2.21)$ & $(2.20)$ & $(2.20)$ \\
\hline Control var & Yes & Yes & Yes & Yes & Yes & Yes & Yes & Yes \\
\hline $\mathrm{N}$ & 487 & 567 & 555 & 635 & 487 & 567 & 555 & 635 \\
\hline \multicolumn{9}{|l|}{ Estimate 3} \\
\hline $\begin{array}{l}\text { Land_Scale } \\
\text { *Trust } \\
\text { Prod_com } \\
\text { *Trust } \\
\text { Land_scale } \\
\text { *Prod_Fc } \\
\text { *Trust } \\
\end{array}$ & $\begin{array}{l}2.189^{* * *} \\
(2.95) \\
13.289^{* * *} \\
(3.00) \\
2.285^{* *} \\
(2.44)\end{array}$ & $\begin{array}{l}2.558^{* * *} \\
(2.70) \\
9.187^{* * *} \\
(2.70) \\
1.585^{* *} \\
(2.20)\end{array}$ & $\begin{array}{l}0.322 \\
(0.21) \\
13.727^{* * *} \\
(2.94) \\
2.624^{* *} \\
(2.20)\end{array}$ & $\begin{array}{l}0.294 \\
(0.96) \\
11.465^{* * *} \\
(3.05) \\
2.478^{* *} \\
(2.34)\end{array}$ & $\begin{array}{l}2.079^{* * *} \\
(2.61) \\
10.300^{* * * *} \\
(3.17) \\
1.421^{*} \\
(1.96)\end{array}$ & $\begin{array}{l}1.736^{* *} \\
(2.50) \\
9.664^{* * *} \\
(3.23) \\
1.238^{*} \\
(1.90)\end{array}$ & $\begin{array}{l}-0.090 \\
(-0.07) \\
10.116^{* * *} \\
(3.19) \\
1.225^{*} \\
(1.85)\end{array}$ & $\begin{array}{l}0.378 \\
(1.07) \\
9.122^{* * *} \\
(3.26) \\
1.106^{*} \\
(1.79)\end{array}$ \\
\hline Control var & Yes & Yes & Yes & Yes & Yes & Yes & Yes & Yes \\
\hline $\mathrm{N}$ & 487 & 567 & 555 & 635 & 487 & 567 & 555 & 635 \\
\hline
\end{tabular}

Note: in brackets are the robust standard errors adjusted by cluster at village level, $*, * *, * * *$ respectively represent the significance levels of $10 \%, 5 \%$ and $1 \%$. In the last column.

\section{Conclusion and Policy Significance}

This paper analyzes the internal mechanism of the formation of cooperatives from the perspective of farmers. Theoretically, this paper analyzes the motivation of farmers' transaction cost reduction by using the transaction cost theory; empirically, this paper uses 635 samples from 307 villages in China's dynamic labor force survey to test the theoretical hypothesis of the nature of operating products and trust on the formation of cooperative groups. 
The conclusion of this paper is that the internal mechanism of the formation of Chinese farmers' cooperatives lies in the reduction of transaction costs. Due to the differences in the nature of planted products, the cooperative behavior of farmers who are mainly engaged in grain crops is affected by the scale of cultivated land; compared with other crops, the probability of cooperative formation increases by 1 point for every 2.22 hectares $(100 \mathrm{mu} / 15=6.67)$ increases of per capita cultivated land scale of grain crops. For the managing commodity crop farmers, their cooperative behavior is affected by the product characteristics; compared with the low commodity crops, the cooperative formation probability of high commodity crops is about $10 \%$ higher. In addition, trust has a positive effect on the formation of cooperatives under the impact of interests; compared with the effect of individual scale and product characteristics effect, the probability of formation of cooperatives under the impact of trust has increased.

The policy implications of this paper are as follows: Firstly, should further refine the agricultural organization management support policies, starting from the product categories of farmers' management, and provide targeted organizational management incentive policies based on the product categories. Secondly, based on the endowment of social capital, the implementation of publicity and education in accordance with local conditions, improve farmers' understanding of the operation mechanism of cooperatives, encourage farmers' awareness of cooperation,andhelp farmers master the operation and management mechanism of cooperatives.

\section{References}

Huang, Z.H. (2000). Farmer cooperation: inevitability, change situation and Enlightenment [J]. China rural economy, 8, 4-8. (in Chinese)

Sun Y.F., Yu H.P. (2012). Analysis on the willingness and influencing factors of the members of farmers' professional cooperatives [J]. China rural economy, 6, 48-58. (in Chinese)

Luo Y.F., Deng H.S., Chen F.F., Xu Z.G. (2017). Farmer participation in Cooperatives:self

Selectionor participation [J]. Agricultural modernization research ,38, 103-110.(in Chinese)

Guo H.D., Jiang W.H. (2004). Analysis of factors affecting farmers' participation in professional cooperative economic organizations based on empirical research on farmers in Zhejiang Province [J]. China rural economy, 5,1016.(in Chinese)

Huang J.K., Deng H.S., Xu Z.G. (2010). Service functions and influencing factors of Chinese farmers' professional cooperative economic organizations [J]. Management world,5,75-81.(in Chinese)

Huang Z.H., Gao Y.L.(2012) The degree of realization of service function of farmers' professional cooperatives and its influencing factors [J]. China rural economy, 7,4-16.(in Chinese)

Deng H.S., Xu Z.G., Huang J.K., Song Y.Q. (2011). Theimpact of organizational potential profits on the formation and development of farmer professional cooperative organizations [J]. Economics (quarterly), 10 (4), 15151532.(in Chinese).

Guo H.D., Yang H.Z., Zhang R.J. (2008). An analysis of the factors affecting the trust of the members of the farmers' Professional Cooperatives: Based on the survey conducted by some members of the Zhejiang Province, [J]., China's rural economy, 8,52-60.(in Chinese)

Zhao Q.M., Li Y. (2007). Relationship network and cooperative economy of rural society in China -- Based on the perspective of social capital [J]. Agricultural economic issues, 8,40-46.(in Chinese)

Xiong W.S. (2009). Cooperatives: unexpected consequences of institutionalization [J]. Sociological research, 24 (5),83109.(in Chinese)

Xu Y. (2007). Howto understand today's farmers, farmers' cooperation and farmers' organizations [J]. Journal of central China Normal University (HUMANITIES AND SOCIAL SCIENCES EDITION), 1,1-3.(in Chinese)

Zhao X.F. (2018). Trust construction, institutional change and the development of farmers' Cooperative Organizations: strategies and practices of standardized development of a farmers' cooperative [J]. China Rural observation, 1,14-27.(in Chinese)

Coase R. H.(1937).The Nature of the Firm[J]. Economics,4,386-405.

Coase R. H. (1960), The Problem of Social Cost.Journal of Law and Economics,3,1-44.

Williamson O. E. (1979).Transaction Cost Economics: The Governance of Contractual Relations.Journal of Law and Economics,2,233-261. 
Appendix Table 1Variable definition and statistical description

\begin{tabular}{|c|c|c|c|}
\hline \multicolumn{4}{|c|}{ Variable $\quad$ Variabl } \\
\hline \multicolumn{4}{|c|}{ Dependent variable } \\
\hline Coopy & Is there have a farmer's Cooperative in this rural area $($ yes $=1$, no $=0)$ & 0.429 & 0.496 \\
\hline Coopy_0 & Coverage of farmers' cooperative in the village $(\%)$ & 13.978 & 30.080 \\
\hline \multicolumn{4}{|c|}{ Independent variable } \\
\hline Land_Scale & $\begin{array}{l}\text { Cultivated land area of the village }(\mathrm{mu}) / \text { Number of population in the } \\
\text { village }\end{array}$ & 3.188 & 3.726 \\
\hline Prod_Fc & The main source of income of the village $($ grain crops $=1$, others $=0)$ & 0.739 & 0.440 \\
\hline Prod_Ec & $\begin{array}{l}\text { The main source of income of the village (general economic crops }=1 \text {, } \\
\text { others }=0 \text { ) }\end{array}$ & 0.453 & 0.499 \\
\hline Prod_Com_1 & $\begin{array}{l}\text { The main source of income of the village (commodity cropsI }=1 \text {, others } \\
=0 \text { ) }\end{array}$ & 0.354 & 0.479 \\
\hline Prod_Com_2 & $\begin{array}{l}\text { The main source of income of the village (commodity crops } \mathrm{II}=1 \text {, } \\
\text { others }=0 \text { ) }\end{array}$ & 0.407 & 0.492 \\
\hline Trust & Relationship between village farmers 0.693 & & 0.462 \\
\hline \multicolumn{4}{|c|}{ Economic conditions } \\
\hline Gdp & Per capita income of the village (ten thousand yuan) & 0.689 & 0.488 \\
\hline N_Agr_Indus & Non-agricultural economy in the village $($ yes $=1$, no $=0)$ & 0.313 & 0.464 \\
\hline Agr_Labor & Total number of households in the village (household) & 77.584 & 26.863 \\
\hline Agr_Out & $\begin{array}{l}\text { Proportion of seasonal migrant workers in thevillage (15-64years old) } \\
(\%)\end{array}$ & 0.191 & 0.202 \\
\hline \multicolumn{4}{|c|}{ Natural conditions } \\
\hline Terrain & $\begin{array}{l}\text { Geographical environment type of the village }(\text { mountain } / \text { hill }=1 \text {, plain } \\
=0 \text { ) }\end{array}$ & 0.410 & 0.493 \\
\hline Disaster & $\begin{array}{l}\text { Types of natural disasters suffered by the village }(\text { drought } / \text { Flood }=1 \text {, } \\
\text { others }=0 \text { ) }\end{array}$ & 0.382 & 0.487 \\
\hline Distance & Distance from the village to the nearest County $(\mathrm{Km})$ & 25.622 & 20.744 \\
\hline \multicolumn{4}{|c|}{ External shocks } \\
\hline Fis_Sub & Agricultural financial subsidies of the village (ten thousand yuan) & 10.881 & 18.404 \\
\hline Fin_Sup & $\begin{array}{l}\text { Whether the village provides agricultural operation expenditure }(y e s=1 \\
, \text { no=0) }\end{array}$ & 0.189 & 0.392 \\
\hline Infor_1 & $\begin{array}{l}\text { Time of the first power on in the village } \quad(\quad 1978=1,1979 \text { - } \\
\left.1999=2,2000_{-}=3\right)\end{array}$ & -2.559 & 0.871 \\
\hline Infor_2 & $\begin{array}{l}\text { Time of the first expressway on in the village } \quad(\quad 1978=1,1979 \text { - } \\
1999=2,2000_{-}=3 \text { ) }\end{array}$ & 2.258 & 1.181 \\
\hline Infrastr & Proportion of hardened pavement in the village $(\%)$ & 0.592 & 0.300 \\
\hline \multicolumn{4}{|c|}{ Farmers' quality } \\
\hline Lead_Skill & The education background of village committee $($ higher $=1$, lower $=0)$ & 0.280 & 0.449 \\
\hline Far_Cogni & Proportion of Party members in the village $(\%)$ & 0.032 & 0.023 \\
\hline Far_Hetro & Top $10 \%$ of the per capita income /Last $10 \%$ of the per capita income & 39.207 & 60.788 \\
\hline
\end{tabular}

